\title{
IMPLEMENTATION OF ENVIRONMENTAL MANAGEMENT SYSTEMS IN THE SLOVAK ENTERPRISES
}

\author{
RUSKO, M. \& KRALIKOVA, R.
}

Abstract: The paper describes the introduction of environmental management systems (EMS) and other pro-environmentally oriented tools in the Slovak enterprises. Industrial enterprises are often some important environment polluters and their activity can represent in large proportion a potential pose of threat for the quality of environment but for safety and health of population too. They present their environmental accountability with various active measures for environment protection. By introduction of the systems of environmental management they create good reputation among environmental associations, state administration and their contemporary or potential business partners, respectively, that may be given is for the society the most interesting aspect among all.

Key words: management, reporting, environment
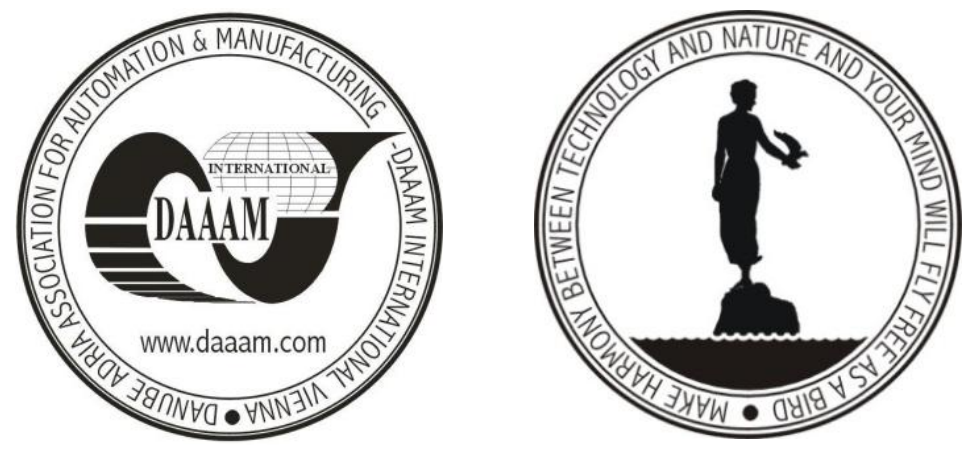

Authors' data: RNDr., PhD. Rusko M[iroslav] *; assoc. prof., Ing., PhD. Kralikova R[uzena]**, *Slovak University of Technology in Bratislava, Faculty of Materials Science and Technology, Institute of Safety and Environmental Engineering, Botanicka 49, 91724 Trnava, Slovakia, ** Technical University in Kosice, Faculty of Mechanical Engineering, Department of Environmental Senses, Park Komenskeho 5, 04001 Kosice, Slovakia, miroslav.rusko@stuba.sk, ruzena.kralikova@tuke.sk

This Publication has to be referred as: Rusko, M[iroslav] \& Kralikova, R[uzena] (2012). Implementation of Environmental Management Systems in the Slovak Enterprises, Chapter 31 in DAAAM International Scientific Book 2012, pp. 369-378, B. Katalinic (Ed.), Published by DAAAM International, ISBN 978-3-901509-86-5, ISSN 1726-9687, Vienna, Austria

DOI: 10.2507/daaam.scibook.2012.31 


\section{Introduction}

When considering the planet Earth, the current human activities are of a global nature. Significant problems include worsening of the environmental conditions. Humanity nowadays has the most modern tools in its whole history at its disposal to influence the environment (both in the positive and negative sense). Unlimited economic growth especially in the states with developed economies, the so-called countries of the rich North, and an exponential growth of human population bring along distortion of certain systems all throughout the planet. The present human civilisation affects the air, climate, soil, water and circulation of substances, live organisms as well as the civilisation itself. Environmental problems caused by human activity are still more and more globalized.

\section{Implementation of environmental management systems}

When considering the planet Earth, the current human activities are of a global nature. Significant problems include worsening of the environmental conditions. Humanity nowadays has the most modern tools in its whole history at its disposal to influence the environment (both in the positive and negative sense). Unlimited economic growth especially in the states with developed economies, the so-called countries of the rich North, and an exponential growth of human population bring along distortion of certain systems all throughout the planet. The present human civilisation affects the air, climate, soil, water, circulation of substances, live organisms as well as the civilisation itself. Environmental problems caused by human activity are still more and more globalized (Brundtland, Gro, Harlem et al., 1991).

In contemporary times the issue of the protection of environment of society becomes a topical theme among the large, medium and also small enterprises. To this fact contribute both legal tools and pressure of non-governmental environmental associations as well as management that started to understand the issue of environment directly touches every subject which parts mainly in production activity.

Industrial enterprises are often some important environment polluters and their activity that can represent in large proportion a potential pose of threat for the quality of environment but for safety and health of population too. They present their environmental accountability with various active measures for environment protection. By introduction of the systems of environmental management they create good reputation among environmental associations, state administration and last but not least at their contemporary or potential business partners, respectively, that is for the society given maybe this most interesting aspect among all.

By the introduction of environmental management systems (EMS) and other pro-environmentally oriented tools, among them belongs the publishing of environmental reports, there is implemented environmental accountability of an organization. By the publishing of environmental reports the organization creates its advertisement both at professional and lay public. 
A recent notion of humanity development identified only with the economic growth has now been corrected so that it would lead also to fulfilment of social goals, in particular to reduction of poverty, enhancement of the quality of life, improved opportunities for better education and health. This change of orientation requires a comprehensive approach to development of mutual relations management between natural and human, branch and structural aspects of development on all levels (Brundtland, Gro, Harlem et al., 1991). As a result of this changed orientation, a concept of sustainable development was created, which is further developed and internationally applied. Since 1960s the knowledge that an unlimited or uncontrolled growth, whether of human population, consumption or pollution etc., is not sustainable under the circumstances of real, existing and limited resources is becoming more wide-spread.

It is, therefore, necessary to replace the model of industrial civilisation by a more sustainable and just concept. Sustainable development concept is nowadays considered as a possible solution for adverse consequences of global trends in society development and their negative impacts on the environment. The emphasis is put on the need to base this concept on healthy ecosystems, strong economy and wellfunctioning social issues.

\section{Voluntary reporting on environment protection}

Environmental reporting is a tool for providing the information about activities of enterprises and their impact on environment. Top managements are aware of the necessity of open and true informing about their environmental activities, which is preconditioned by the creation, maintenance and following improving of the system of environmental informing in enterprise.

By the accession of the Slovak Republic to European Union there was risen the need of guaranteed information in the framework of environmental reporting.

Potential benefits of voluntary reporting on environment protection:

- raises of the confidence at shareholders, warrantors and investors,

- simplifies the accession to capital and investment markets,

- raises the confidence of bank supervision,

- improves the competitiveness,

- raises motivation and satisfaction of employees,

- improves communication with stakeholders’ parts (Environmental reporting, 2001).

In practise, the environmental report can be apprehended as a tool for improving both societal and business relations, for determination details and elaborated verification of business' environmental goals, procedures, strategies and future steering of the enterprise in the sphere of environment protection. 


\section{Environmental communications}

Good communication is a basement for right functioning of environmental management system. The environmental management system (EMS) contains the reasons why to give information to the stakeholders inside and outside the organization. There can be financial institutions, or neighbouring communities that can ask for publishing of document on information on the organization activities in the range of environment protection. The sense of such an activity is to support the public appreciation of the organization.

The goals of the communication on environment protection:

- to satisfy the demands of banks and financial groups that relate to the reporting on environment protection implementation,

- to inform the organizations with contact,

- to create a system for facilitation of communication with public an for reporting on environment protection implementation,

- reduction of number of complaints,

- raising of the belief between the enterprise and its warrantors.

\subsection{Environmental reporting}

Environmental reporting is a tool that gives information on the organization's activities and their influences on environment. The target groups are mainly business partners (also the potential ones), employees, offices and environmental governmental and non-governmental organizations.

Nowadays, the enterprises are due to keep, on the basis of legal regulations in the sphere of environment, prescribed records on their share on environment pollution, in water and waste management, dangerous chemicals charging and so on. These records are regularly provided for state environment administration. In the framework of this reports there started many enterprises to public their first environmental reports.

The emergence of environmental reporting was initiating by the reaction of industrial enterprises as well as state institutions engaged in environmental protection to industrial accidents that raised public upset from possible negative consequences for its life. In 1985 CCPA had established basements for Programme of Responsible Care. According to this Programme the managements of enterprises have to try to communicate with communities in the region that are influenced by their activities, that means, that the enterprises that adopted Responsible Care have to inform on their environmental activities. Responsible Care is an reaction of chemical industry to this interest.

Implementation of EMS/EMAS helped to important broadening of environmental reporting, where the enterprise is due to inform on its environmental policy. 
The advantages of environmental reporting:

- better feelings of employees - they are doing something for themselves and for their surrounding,

- initiates good relationships between the enterprise and environmental associations,

- contributes to the improvement of the enterprise name on the market and between broad public.

- Environmental reports contain mostly these items:

- introduction by the director of organization,

- history of organization,

- environmental policy of the organization,

- global status of the organization with respect to the environment,

- realized development towards the fulfilment of specific tasks defined in previous report,

- formulating new tasks or activities for improving environmental behaviour of the organization in future.

\subsection{Environmental reports}

The environment protection is now in the midpoint of interests of broad expert and lay public and reflects itself globally in the business sphere. It is evident in raising interest of stakeholders' parts in the impacts of activities, products and services on health of population and environment. From this reason the enterprises are forced to conduct more considerate with respect to environment. i. e. to take full responsibility for the impacts of their products, services and activities on the environment. Top managements and owners of enterprises are aware of the inevitability of open and true informing on their environmental activities that means supposing creation, keeping and later bettering of the system of environmental information in the organization. Main reasons for the environmental reports publishing are:

- demands of stakeholders,

- legal demands of individual countries.

The environmental reports can be presented at various levels:

- global (e.g. the Report Our Common Future, The Reports of Roma Club and suchlike.)

- national (e.g. Report on the environment of the Slovak republic regularly published by the Ministry of environment of SR every year, report Rio+10 10 (Klinda, J. et al., 2002)

- regional, municipal reports,

- reports of enterprises. 


\subsection{The reports on the environment of the $S R$}

The Reports on the environment of the Slovak republic share the common fact that they are based on statistic data and information coming from the Ministry of environment of the SR (MoE SR), Statistic Office of the SR, expert organizations of the MoE SR branch and their expert parts. The Reports on environment publishing belongs to the duties demanded by the Aarhus convention of 1998. Such reports belong to the national environment reporting. The Directive of European parliament and Council No. 2003/35/ES of May 26, 2003 issued for ensuring of consistency of community legislation with the 2 nd pillar of the Aarhus convention. It is implemented to Slovak legal system by:

- Act of NC SR No. 24/2006 Coll. On environmental impact assessment,

- Novelized Act NC SR No. 245/2003 Coll. On integrated prevention and pollution control.

- Selected sorts of reports dealing on national reporting are as follows:

- reports on environment status according to the D-P-S-I-R structure,

- reports on the economy branches influences on the environment of the SR (sectoral reports) - process of environmental impact of selected sectors of economic activities assessment,

- regional reports on environment status,

- information leaflets on the environment of the SR.

\section{Assets of environment reports issuing}

The essence of the environment reporting is a process of collection, processing, analysis, evaluation or verification, resp. and finally announcement of selected important, useful information on the impacts of enterprise's activities, products and services on environment towards the stakeholders' groups of users and getting the positive mutual relation with them. By evaluation of the enterprise management can adopt measures for fulfilling of global environmental goal of the enterprise, i.e. helping by its activities to the process of sustainable development contributing to the environment status betterment.

Implemented and reliable functioning EMS is prerequisite of this goal fulfilment.

Assents of environment reporting are different at every enterprise. Commonly there can be considered these assets of environment reporting:

- purvey the documents for permanent EMS of enterprise betterment,

- raising employees motivation,

- possibility for positive „green“ image utilisation at creditors' and investors' persuasion on enterprise interests in environment,

- functioning environmental reporting and good made environmental audits can show possibilities of communication with stakeholders improvement, 
- possibility to emphasize an environmental profile of enterprise an getting, in this way, an attention at business negotiations,

- introduction of environmental aspects among main priorities of enterprise.

\section{Standardization of environment reports}

The procedures according the standards of ISO 14000 are the most important common standard "STN EN ISO 14063: 2010" Environmental management; Environmental communication. Instructions and examples (ISO14063: 2006) are directed to the communication issues.

World Business Council of Sustainable Development (WBCSD) on its web-site presents publications and reports. WBCSD did not publish any directive on environment reports. These projects are more contemplation on sustainable development than any instruction how to write any report.

The Global Reporting Initiative (GRI) started issuing some Sector Supplements that are supplements of GRI Directive. The report plan is prescribed like the indicators' selection.

The International Network for Environmental Management initiative (Clausen, J. at al., 2001) advocates the report structure and indicators types for every sphere but gives much more freedom to the report creator than the GRI Initiative. This tool gives advices how to elaborate good report on sustainable development. It is aimed on economic interests of enterprise presentation as well as on reliable and persuasive communication, informing of stakeholders and their interests at the region of information structure, features the development sustainability report principles and elements and gives a sum of good examples for enterprise presentation. Except of this, it draws attention to the reliability of the sustainable development report. This handbook is based on INEM sustainability reporting and general GRI principles.

The Responsible Care is a world-wide initiative trying on continual improvement of all aspects of health, safety and environment protection in chemical industry and raising of open communication on its activities and reached results (***Responsible Care, 2011).

\section{Types of enterprise environmental reports}

The enterprises can provide environmental information by two means:

- voluntary reports - enterprises issue environmental information on commitments, sustainable development or as separated reports (enterprises decide alone how to give the most transparent information to the stakeholders' groups),

- obligatory reports - enterprises often present environmental issue as parts of annual reports.

- The types of voluntary environment reports are as follows: 
- Environment report (TYPE I) - enterprise' care for environment;

- Environment report - HSE (TYPE II) - enterprise' care for health, safety and environment;

- Environment report - UR (TYPE III) - sustainable development of the enterprise - economic, environmental, social;

- The Report on responsible enterprise (CSR) - ethical behaviour of enterprise towards the society in the financial, environmental and social spheres.

\section{Survey on environmental reporting of the SR enterprises having}

Management of industrial enterprises realizes, in accordance with EMS or EMAS implemented the need for the enterprise' activities management together with environmental reporting. The implemented systems of environment management demand to create some system of communication on the environmental profile of enterprise with stakeholders. The EMA programme prescribes a written form of environmental information providing and their releasing procedure.

In 2010 we were realizing the survey aimed to environmental information provided by enterprises in the SR having EMS, or EMAS, resp. implemented via internet. There were 375 enterprises included in this survey.

Environmental information of the enterprises, having EMS or EMAS implemented that were issued on their web-sites were categorized as follows (Fig.1):

A - information on EMS implementation, F - water quality protection,

B - information on EMAS implementation, G - waste management,

C - environmental report, $\mathrm{H}$ - vegetation care,

D - environmental policy, I - safety and industrial hygiene reports, $\mathrm{E}$ - air quality protection, $\quad \mathrm{J}$ - another activities.

Under the heading "other" there are hidden some activities of various character, like:

- envirnonmentally appropriet product certificate,

- contributions to environmental programmes,

- Responsible Care,

- old environmental burdens,

- cooperation with NGOs at the environmental policy implementation (e.g. SKANSKA Technologies Ltd., that in cooperation with Ekopolis Fundation has created the "People for Trees" Programme),

- and various other activities at environment issues. 


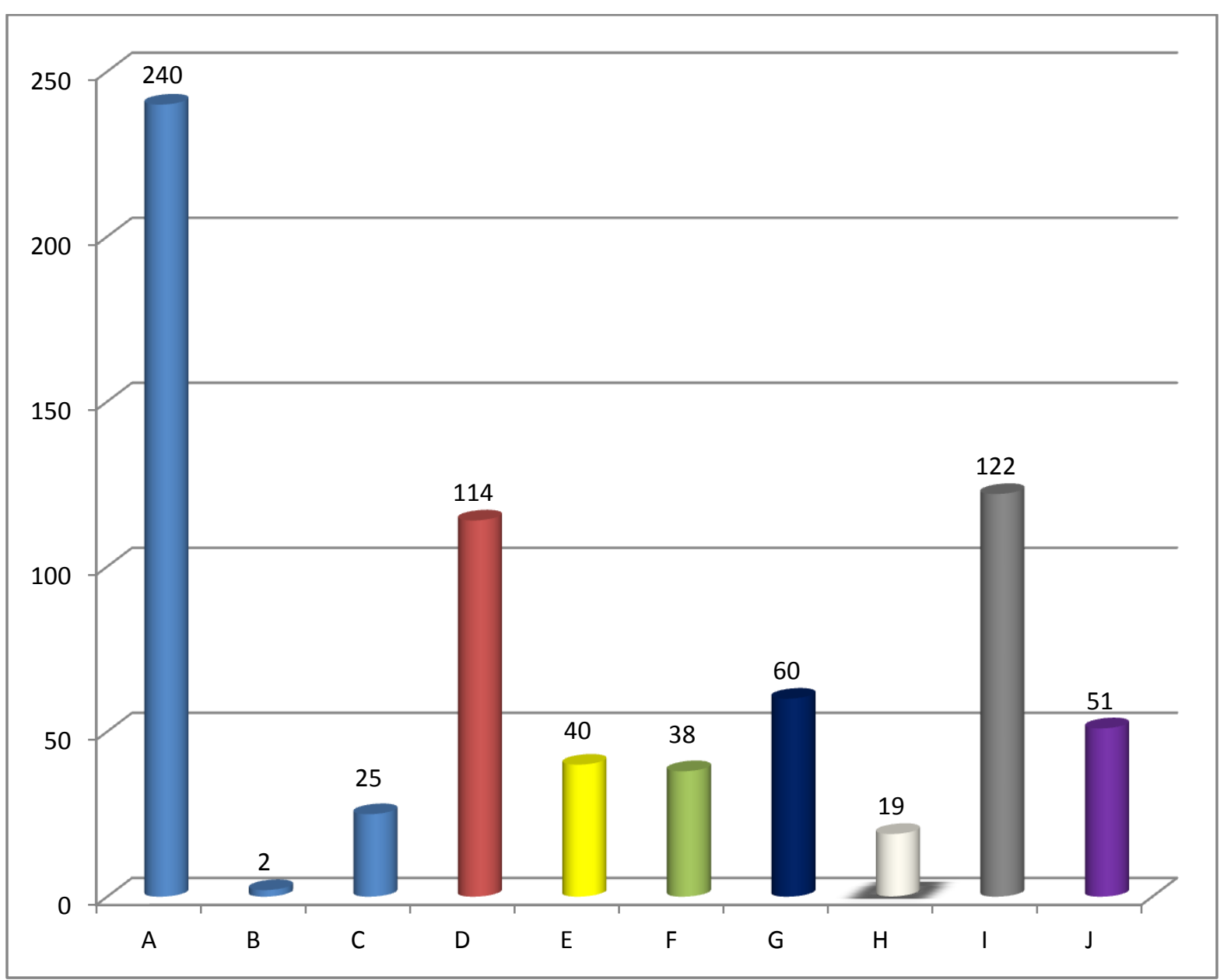

Fig. 1. Categories of eenvironmental information of the enterprises

\section{Results}

The most accessible form of presentation of environmental reports is their issuing on web-sites where they are available for every interesting subject. It is important for an enterprise to establish some ladder of values according that will the enterprise present its profile to the public. Environmental report, as any other information, has to be objective and true in relation to receiver (stakeholders' parts). It has to be a part of an integrated information system of the enterprise too.

The environmental reporting is implemented mainly by large and profiting enterprises. Small and medium enterprises include it to their annual reports.

We can see a positive importance of environmental reporting in the informing not only of fulfilment environment protection regulations but on pro-environmental approach of the enterprise as such. The environmental reporting enables the communication on activities with stakeholders. The main goal of environmental information publishing is therefore a presentation of the enterprise attitude to the environment. 
Rusko, M. \& Kralikova, R.: Implementation of Environmental Management Systems in ...

\section{Acknowledgements}

This contribution was worked - out frame within the frame project $\mathrm{N}^{0} 032$ TUKE-4/2012 „ICT aided new forms of learning and increasing the efficiency of education for environmental study programs".

\section{References}

Andrejiova, Miriam (2011) Attestation of assumptions about random error of the regression model. In: Creative Mathematics and Informatics. Vol. 20, no. 1 (2011), p. 4-7. - ISSN 1584-286X

Brundtland, Gro, Harlem et al.(1991). Our common future. Praha. Academia. 297 p. ISBN 80-85368-07-02

Clausen, J.; Loew, T.; Klaffke, K.; Raupach,M. \& Schoenheit, I. (2001): The INEM Sustainability Reporting Guide. A Manual on Practical and Convincing Communi-cation for Future-Oriented Companies. Berlin: International Network Management (INEM) Institut für ökologische Wirtschaftsforschung (iöw). imug Institut für Markt/Umwelt/ Gesellschaft. $61 \mathrm{pp}$

Klinda, J. ; Bebej, J. \& Toma, P. (2002). RIO + 10 REPORT. Bratislava. ISBN 80888-33-31-0

Knezo, Dusan; Andrejiova, Miriam \& Izaríkova, Gabriela. Basic statistical methods ,Kosice, Slovakia, 184 pp.. ISBN 978-80-553-0841-8

Kozakova, Lubica - Estokova, Adriana \&Mihalikova, Renáta (2012): Environmental Management Košice . - 81 pp. - ISBN 978-80-553-1077-0

Kralikova Ruzena, \&Mihalikova, Renáta ( 2009). Product life cycle management applications In: RIM 2009: Development and Modernization of Production, Cairo, Egypt, University of Bihać P. 207-208. - ISBN 978-9958-624-29-2

***Environmental reporting, General Guidelines. Defra, 2001, ISBN 80-8073-354-6, p. $9-14$

***http://www.americanchemistry.com. Responsible Care. Accesed on: 2011-02-05 ***http://www.epa.gov/ems/info/index.htm. Environmental Protection Agency USA. Environmental Management Systems. Accesed on: 2011-02-18

***http://sdo.ew.eea.europa.eu/tools/inem-sustainability-reporting-guide.

INEM

Sustainability Reporting Guide. Accesed on: 2012-03-11

***http://www.inem.org/.International Network for Environmental Management. Accesed on:2011-03-07 